\title{
CONSTITUTIONALISM AND JUDICIALIZATION OF POLITICS: THE "JUDICIAL" RIGHT TO HEALTHCARE IN BRAZIL
}

Bruno Irion Coletto

Master'sstudent inthe Politics Department at the New School for Social Research in New York City. He holds a J.D.cum laude and a LL.M. from the Federal University of Rio Grande do Sul, Brazil.

coletto.bruno@newschool.edu

Pedro da Silva Moreira

Doctoral student inPhilosophy of Law at the Universidad Autónoma de Madrid. He holds a J.D. and a LL.M. from the Federal University of Rio Grande do Sul, Brazil.

psmoreira@gmail.com

\begin{abstract}
The right to healthcare in Brazil is seriously protected by the courts. Judicialization of everyday implementation of this public policy is a fact. One explanation may be provided by the way judges understand the effectiveness of this right. People hold subjective right to individualized healthcare benefits, and so they hold standing to sue the state in order to achieve it, regardless any consideration of public policies. Through an analysis of the jurisprudence on this issue, this paper aims to provide a critical understanding not just about what is actually happening in Brazilian courts regarding healthcare, but also to criticize it. The conclusion is that a "strong" conception of constitutionalism and fundamental rights may revel itself as "weak," from the standpoint of general equality. Judicialization ends up empting the public debate, leading the task of solving the distribution of scarce resources to a "gowned aristocracy."
\end{abstract}

Keywords: Judicialization of Politics - Right to Healthcare - Weak Judicial Review - Political Identity 
"The law shall not exclude any injury or threat to a right from the consideration of the Judicial Power" is one of the most incontrovertible statements of the Brazilian Constitution. ${ }^{1}$ Provided as individual guarantee under Article 5 - inserted in the chapter on "individual rights," those kinds of rights which Bobbio once called "first generation rights" since they demand a negative provision from the State - this norm has been the constitutional basis for individual lawsuits against the State in Brazil. These lawsuits aim, however, provisions framed under the "second generation rights,"3 as far as the claim is for "social and economic rights," such as those stated in Article 6 of the Brazilian Constitution. In other words, the lawsuits claim on individual basis for healthcare, education and housing, rights which require a "positive provision" from the State in a collective basis. ${ }^{4}$

Under the Universal Declaration of Human Rights ${ }^{5}$ it is possible to observe the same kind of rule. More than providing substantive rights, such as freedom, equality, non-discrimination, life, safety, freedom from slavery and torture, etc.; the Declaration also ensures two "procedural" provisions. Article 8, with a similar meaning to the Brazilian constitutional provision quoted earlier, establishes that "Everyone has the right to an effective remedy by the competent national tribunals for acts violating the fundamental rights granted him by the constitution or by law;" and, for this to perfectibilize, Article 6 provides the recognition of legal personality to everyone, everywhere. Thus, everyone, everywhere, carries standing to fill out a lawsuit to claim for fundamental rights.

The idea that to each existing right there is a correspondent lawsuit, or action, is not new. It is intrinsic to the theories of subjective rights remember, for instance, the classic discussion between the theories of the will and interest carried out from Savigny, Windscheid, Jhering and Jellineck -; and it was expressly provided in Article 75 of the former

\footnotetext{
1 The Brazilian Constitution's English version is available at the Brazilian Supreme Court website. All English quotations from the Constitution are made from there. Available at http:// www.stf.jus.br/repositorio/cms/portalStfInternacional/portalStfSobreCorte_en_us/anexo/ constituicao_ingles_3ed2010.pdf

2 BOBBIO, Norberto. A Era dos Direitos. Trad.: Nelson Coutinho. Rio de Janeiro: Elsevier, 2004, pp. 62-3.

3 BOBBIO, Norberto. A Era dos Direitos, 2004, p. 63.

4 LOPES, José Reinaldo de Lima. "Direito Subjetivo e Direitos Sociais: o dilema do Judiciário no Estado Social de Direito.”Direitos Humanos, Direitos Sociais e Justiça, Ed. José Eduardo Faria. São Paulo: Malheiros, 2002,"pp. 126-7; SILVA, Virgílio Afonso da. "O Judiciário e as políticas públicas: entre transformação social e obstáculo à realização dos direitos sociais." In Direitos Sociais: fundamentação, judicialização e direitos sociais em espécies, edited by Cláudio Pereira de Souza Neto and Daniel Sarmento. Rio de Janeiro: Lumen Juris, 2008: 58799, pp. 589-591.

5 Available at http://www.un.org/en/documents/udhr/
} 
Brazilian Civil Code, current between 1916 and 2002, which literally stated that "to each right, corresponds an action that ensures it."In a similar sense, Kelsen's Pure Theory of Law argues that one only can think of subjective rights by recognizing that there is an obligation of noninterference, what is the same to say that there is subjective right when it is acknowledged that a prior obligation was established first to another person. ${ }^{6}$ All these ideas of subjective rights and capacity for moving legal actions are part of the legal imagination: for a Brazilian jurist it is natural to correlate subjective right with action (lawsuit) against someone who has the obligation to provide something. The question, then, is how to understand social rights in this individualistic context and language.

We will not deal with theory of action here, though. By writing in a foreign language on a "Panorama of Brazilian Law," and by having as readers international legal and political community interested in better understanding Brazilian law, we are going to draw our panorama from the point of view of what has been called "judicialization of politics." The transposition of the political arena to legal courts is now well spread all around the world - especially in recent decades with the general acceptance of the idea of supremacy of the constitution ${ }^{7}$ - in a phenomenon that has been called "new constitutionalism." We acknowledge that the expression "judicialization of politics" is broad and has been used as an umbrella to describe different related phenomena by giving them different meanings. ${ }^{8}$ Here, we will limit the focus by the study of a recurring situation in the Brazilian courts.

As pointed out by Hirschl, the judicialization of politics usually "has been accompanied by the concomitant assumption that courts - not politicians or the demos itself-are the appropriate forums for making these key decisions." ${ }^{\prime 9} \mathrm{He}$ differentiates at least three types of judicialization ${ }^{10}$ : the first is portrayed in the use of speech and legal practices in the fields considered primarily political, what can be called "judicialization of social relations;" "11 the second is portrayed as the judicialization of decisions on public policy, especially by challenging, in courts, the procedural aspects of public policies, which may be called "judicialization from below," since "it is often initiated by right claimants who challenge public policy

6 KELSEN, Hans. Pure Theory of Law. Translated from the Second Edition by Max Knight. Berkeley: University of California Press, 1967., 125-45, 168-71.

7 HIRSCHL, Ran. "The New Constitutionalism and the Judicialization of Pure Politics Worldwide." Fordham Law Review 75, n. 2 (2006): 721-54, p. 721. Available at SSRN: http:// ssrn.com/abstract $=951610$.

8 HIRSCHL, Ran. “The New Constitutionalism,”2006, p. 723.

9 HIRSCHL,Ran. "The New Constitutionalism,"2006,p. 722.

10 HIRSCHL,Ran. “The New Constitutionalism,”2006,pp. 723-9.

11 HIRSCHL,Ran. "The New Constitutionalism,"2006,p. 725. 
decisions and practices;" 12 and, finally, the third is portrayed as the judicialization of the most important political issues, the "mega-politics matters of outright and utmost political significance that often define and divide whole politics."13

Our attention, by following this classification, is concentrated on three key questions: what kind of understanding of the fundamental rights supports the broad judicial protection of social rights? Is there such a thing as a "weak" way to think those rights which could, paradoxically, make them "stronger?" Finally we wonder, thinking over Hirschl thoughts: how does the judicialization of public policies influence the most sensitive political issues in Brazil? Or, raising the question using Hirschl's own terms: how the "judicialization from below" - which interferes significantly in the realization and even in the nature of a given public policy - might end up reflecting on the "mega-politics?"

Those problems are our backdrop. We will face those issues by observing the judicial position in the judgment of individual demands for drugs and healthcare provisions that are not provided by public policies. ${ }^{14}$ Brazilian courts have given broad effectiveness to the fundamental right to healthcare: It is a paradigmatic case of "judicialization of politics." Worth mentioning that we are not just talking about courts granting expensive or experimental (i.e. with no scientific proved efficacy) treatments - which are granted by courts in a daily basis -, but we are also referring to alternative treatments and ones of controversial essentiality, such as oxygen therapy, ${ }^{15}$

12 HIRSCHL, Ran. “The New Constitutionalism,”2006, p. 725.

13 HIRSCHL, Ran. "The Judicialization of Mega-Politics and the Rise of Political Courts." Annual Review of Political Science 11 (2008), p.2. Available at SSRN: http://ssrn.com/ abstract $=1138008$.

14 Therefore, actions in which the plaintiff demands drugs that should be provided according to the public policies' list, but which were not provided because of some problem in the implementation of such public policy will be excluded from the scope of this paper. Vieira and Zucchi refer to these actions as "justified," since the public policy expressly stipulates that such medication should be provided to anyone freely. Our concern in this piece is with the lawsuits they see as "unjustified:" "it would not appear reasonable for people to request medications and healthcare products when there is already an established and high-quality treatment policy. Nor would it appear reasonable to request products of doubtful efficacy and of a cost that is prohibitive to the health system, thereby compromising thousands of other people's access to medications by exhausting the budget" (VIEIRA, Fabiola Sulpino; ZUCCHI, Paola. "Patient Lawsuits and Treatment Provision on the Brazilian National Health Service." Revista Associação Médica Brasileira 55, n.6 (2009): 672-83. Available at www.scielo.br. 15 TJ/RS, 3a Câmara Cível, Apelação Cível n. 70059548180, Rel.: Nelson Antônio Monteiro Pacheco, j. 26.03.2015. In a quick search using the parameter "oxygen therapy" at the TJ/RS website research tool we found more than 700 legal cases that were already ruled just in this appeal court. 
speech therapy, ${ }^{16}$ acupuncture,${ }^{17}$ hydrotherapy, ${ }^{18}$ homecare, ${ }^{19} \mathrm{IVF}^{20}, \mathrm{ED}^{21}$, and even equine therapy ${ }^{22}$ - all paid by the public and free healthcare system.

This paperwillnot only describe what the Brazilian judges are doing - although we spend a good length doing it. Our goal is to present a critical overview: through criticism it is possible to realize what is at stake, especially when the topic is related to law and politics. By means of the judicial realization of the right to healthcare in Brazil case, we are, in fact, raising one of the key political questions: who should implement the "constitutional promises?" After presenting in Chapter 1 a descriptive overview of the court rulings in Brazilian courts, in Chapter 2 we will raise some arguments that are completely ignored by the mainstream debates regarding the topic. We believe the overlooked idea of a nonlegal protection of rights addresses several essential issues related to the justiciability of social rights. Finally, in Chapter 3, we will bring a word about the (arguably) "legal" reasoning that has been used in courts in cases such as those analyzed here, in order to try to rescue the political and democratic features of the implementation of the Constitution.

\section{An Overview on Judicial Rulings Based on the Right to HealthCARE IN BRAZIL}

\section{On the Constitutional Provision of Right to Healthcare and the Selection of Judicial Decisions Presented}

We have already mentioned that the Brazilian Constitution, in force since 1988, imbued with the spirit of the welfare state, in addition to "individual rights" also provides a wide range of "social rights" that demands for a positive action from the State, ${ }^{23}$ such as healthcare. The

16 TJ/RS, 2a Câmara Cível, Apelação Cível n. 70062063896, Rel.: Ricardo Torres Hermann, j. 19.12.2014.

17 TJ/RS, 21 a Câmara Cível, Relator: Des. Francisco José Moesch, Apelação Cível n. 70035728492, julgado em 28.07.2010.

18 TJ/RS, 8a Câmara Cível, Relator: Des. Ricardo Moreira Lins Pastl, Apelação Cível n. 70047926647, julgado em 24.05.2012.

19 TJ/RS, $21^{\text {a }}$ Câmara Cível, Rel.: Marco Aurélio Heinz, Apelação Cível n. 70062799317, j. 11.02.2015.

20 TJ/RS, 22 ${ }^{\text {a }}$ Câmara Cível, Rel.: Denise Oliveira Cezar, Agravo de Instrumento n. 70058803040, j. 18.12.2014.

21 TJ/RS, $1^{\text {a }}$ Câmara Cível, Relator: Des. Luiz Felipe Silveira Difini, Apelação Cível n. 70048376131, julgado em 09.05.2012.

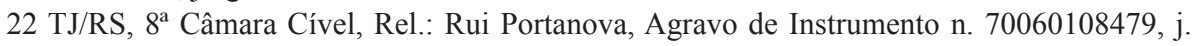
03.07.2014.

23 LOPES, José Reinaldo de Lima. "Direito Subjetivo e Direitos Sociais: o dilema do Judiciário no Estado Social de Direito", 2002, pp. 126-7; SILVA, Virgílio Afonso da. “O Judiciárioe as 
pursuit of reducing social inequalities is a national goal reflected in the current Constitution - which is customarily called "Citizen Constitution," precisely because it has numerous social rights guaranteed in its legal text. Social rights, accordingly, are considered a condition for democracy. ${ }^{24}$ Yet, more importantly to the practice of law, Brazilian Constitution provides in the first paragraph of the Article 5 that such rights are immediately applicable, meaning that those rights are not merely a program, a goal, or a promise, but something that can and should be implemented straightaway: "Paragraph 1. The provisions defining fundamental rights and guarantees are immediately applicable." What this prediction means, in fact, is also one of the concerns raised in this paper.

With regard to the right to healthcare, ${ }^{25}$ it is provided in Article 6 in general and more abstract fashion, ${ }^{26}$ listed among the social rights; and in the Article 196 in a concretely way. ${ }^{27}$ This last statement is in a part of the chapter titled "Social Welfare, which "comprises an integrated whole of actions initiated by the Government and by society, with the purpose of ensuring the rights to health, social security and assistance," ${ }^{28}$ having as one of its mostly referred principles the "universality of coverage and service." 29 All this constitutional regulations are at a broader title dealing with what is called "social order," which "is based on the primacy of work and aimed at social well-being and justice." 30

There is no doubt, therefore, that Brazilian State (whether federal, state or municipal levels) ${ }^{31}$ is constitutionally obliged to

políticas públicas: entre transformação social e obstáculo à realização dos direitos sociais," 2008, pp. 589-91.

24 Lopes, José Reinaldo de Lima. "Judiciário, democracia, políticas públicas.” In Revista de Informação Legislativa 31, n. 122 (Mai/Jul, 1994): 255-265, p.256.

25 Brazilian Constitution (and Brazilian lawyers in general) uses the Portuguese expression "right to health" meaning both an broader idea, the principle, that everybody in the country should be health, and that healthcare should be provided to everyone by the State - which means all Federal, State and Municipal Governments - on a free basis.

26 Article 6. Education, health, food, work, housing, leisure, security, social security, protection of motherhood and childhood, and assistance to the destitute are social rights, as set forth by this Constitution.

27 Article 196. Health is a right of all and a duty of the state and shall be guaranteed by means of social and economic policies aimed at reducing the risk of illness and other hazards and at the universal and equal access to actions and services for its promotion, protection and recovery

28 Article 194.

29 Article 194, sole paragraph, I.

30 Article 193.

31 It is worth mentioning that the Brazilian federalism divides the responsibilities for healthcare between the Union (federal government), states and municipalities. Medicines to treat high complexity diseases or with high cost are in the Union's competence. Less complex medicines are, in turn, in states' level of attribution. Finally, the most basic medicines are in municipalities' level. 
provide universal healthcare for all Brazilian citizens. In other words, three constitutional provisions read together - the one that says threats to rights cannot be excluded from consideration of the judiciary branch; the one that states fundamental rights are immediately applicable; and the one that declares right to healthcare as universal - are granting the grounds for individual ${ }^{32}$ lawsuits filled out by citizens against the government demanding not only for medicines and treatments prescribed by public policies, but also claiming for benefits not provided by the public policies, which can include up to experimental treatments with no confirmed efficacy and even treatments that have not been approved by the regulatory agency.

To give an idea of the dimension of the issue, in November 2013 were being handled in Brazilian courts more than 221,000 lawsuits under the right to healthcare label, and of these, only in the state of Rio Grande do Sul (which has around 11 million inhabitants, representing $5.5 \%$ of the national population), there were more than 113,000 cases waiting to be ruled by a judicial court. It is more than half of whole country's cases. In its turn, the State of São Paulo, with more than 41 million people $(21.7 \%$ of the population), was processing over 44,000 cases in the same period. Rio Grande do Sul's numbers are impressive, especially when one considers that in that year, out of $\mathrm{R} \$ 316$ million spent by the State Government with drugs, R\$ 192 million were to comply with court orders - representing more than $60 \%$ of State's budget to healthcare. ${ }^{33}$ Putting it in clear terms: members of the judiciary decided in individual and concrete cases how to spend more than $60 \%$ of the budget for that period. For this reason, considering that the vast majority of cases come from the same state of the federation, we limit ourselves to closely analyzecases from the Rio Grande do Sul's State Court (TJ/RS, acronym in Portuguese). Those should be sufficient to provide an overview on the issue in Brazilian courts. ${ }^{34}$ Eventually, we

32 That is, it is not a class action, which details are outside the scope of this work. A good insight into the issue of collective actions can be found at LOPES, José Reinaldo de Lima. "Brazilian Courts and Social Rights: A Case Study Revisited." In Courts and Social Transformation in New Democracies: An Institutional Voice for the Poor?, edited by Roberto Gargarella, Pilar Domingo, Theunis Roux, 185-211. Hampshire: Ashgate Publishing, Ltd., 2006.

33 TREZI, Humberto; OTERO, Julia. "Com 113 mil processos, RS é campeão nacional em ações judiciais na saúde."Jornal Zero Hora. November 17th, 2013. Available at http://zh.clicrbs.com.br/rs/noticias/noticia/2013/11/com-113-milprocessos-rs-e-campeao-nacional-em-acoes-judiciais-na-saude-4336052.html See also: CAVALCANTI, Hylda. Brasil tem mais de 240 mil processos na área de Saúde. Site do CNJ. April25th, 2011. Available at http://www.cnj.jus.br/noticias/ cnj/14096:brasil-tem-mais-de-240-mil-processos-na-area-de-saude.

34 It must be said that there is a lack of detailed quantitative research on the lawsuits in this state. There are some data available about the situation in the states of São Paulo and Rio de Janeiro - the most populous in the country - which will be referred below. Investigatethe 
will quote cases ruled by Brazilian Supreme Court (STF), since it is the highest judicial body in the country, which sets the guidelines for the courts and ordinary judges.

We will present also some findings of data research already carried out in the States Courts of São Paulo and Rio de Janeiro - which are the next in the number of individual cases in courts. ${ }^{35}$ With respect to this choice, we need to note the absence of quantitative research on the cases of the Rio Grande do Sul's State Court. Thus, in spite of the fact that the data reported here are from different state courts, we believe that they serve to at least illustrate our argument and, more importantly, to enrich the discussion we are proposing here.

\section{Decisions from Rio Grande do Sul's State Court, the Existing Data and the Brazilian Supreme Court}

The right to healthcare is articulated as a corollary of the right to life. Health / life connection is the most touching argument present in the observed cases, but it is not the only argument that has based decisions on right to healthcare. By analyzing different judgments from $\mathrm{TJ} / \mathrm{RS}$, available on their website, we identified three most frequent kinds of arguments for granting medicines and healthcare treatments: the argument of life, the presumption of truthfulness of the prescription and the immediate applicability of any right (as opposed to the idea that the Constitution has provided merely a program of rights). The latter argument has also been referred by the STF, which, from that, had even grounded decisions based on the "right to hope," as we shall see later on.

The first argument to support large concession of drugs through judicial means can be summarized as follows: life is the greatest good of all - and law protects the greatest good - so that legal or political arguments can never serve to limit such fundamental right. ${ }^{36}$ The

reasons why one statehas more than halfof this kind of lawsuits would be a taskfor another article.

35 Data from 2013 shows that from the 221,323 lawsuits waiting for a judicial ruling in the whole country, 113,953 were active in Rio Grande do Sul; 44,690 in São Paulo; and 25,234 in Rio de Janeiro (TREZI, Humberto; OTERO, Julia. "Com 113 mil processos, RS é campeão nacional em ações judiciais na saúde", 2013.

36... a fundamentalidade do direito à saúde faz com que sua garantia seja a expressão de resguardo da própria vida, maior bem de todos. Alegações de questões principiológicas não se sobrepõem à necessidade de garantir o direito fundamental ameaçado, o que justifica a ordem de fornecimento gratuito dos medicamentos pleiteados(Apelação Cível No 70060969946 , Segunda Câmara Cível, Tribunal de Justiça do RS, Relator: Laura Louzada Jaccottet, Julgado em 05/12/2014).

We have kept the original Portuguese in the quotations from court rulings, as well as we have maintained the pattern of Brazilian referral to indicate the case. This was meant convey the original idea and to facilitate the localization of the cases. All court rulings are available at the 
equalization between right to healthcare and the "right to life" has also justified the view that no regular norm or statute (such as the regulation of the healthcare system) can limit the right provided by the Constitution. ${ }^{37}$ Consequently anything requested in those terms must be provided by the State, even if it is not provided in that way by public policy. In the same vein comes the argument that it is impossible to quantify life, then arguments based on the high costs of some medicine (which in this case had not been approved by the regulatory agency for pharmaceuticals issues in Brazil) do not serve to justify the denial to grant a treatment that may save a life. ${ }^{38}$ Still, thirdly, there is the argument that, using a false collision of principles (borrowing Robert Alexy's terminology), opposes plaintiff's right healthcare against public budgetary interest, saying that healthcare is more important than State's finances. ${ }^{39}$ Finally, the "right to life" has sustained not only the provision of treatments in life risk cases, but also has justified rulings in cases where a life does not yet exist: based on the "right to life," Courts have granted infertility treatments. ${ }^{40}$

The second group of arguments used to grant the claim is not

courts websites.

37 I - O direito à saúde é direito social (art. $6^{\circ}$ da CF/1988) e dever do Estado (art. 196 da CF/1988 e 241 da CE/1989) e está intimamente ligado ao direito à vida e à dignidade da pessoa humana; tem estatura de direito fundamental, seja no sentido formal, seja no sentido material, nos termos do parágrafo primeiro do consagrado art. $5^{\circ}$ da Constituição da República. II Desnecessária a previsão em lista de medicamentos essenciais ou especiais ou excepcionais da Administração, pois atos normativos não se sobrepõem à norma constitucional (Apelação Cível N ${ }^{\circ} 70062771910$, Terceira Câmara Cível, Tribunal de Justiça do RS, Relator: Eduardo Delgado, Julgado em 05/12/2014).

38 O princípio da reserva do possível não se aplica, data vênia, quando se está diante de direitos fundamentais, como ocorre no caso concreto, em que se busca preservar a dignidade da vida humana, consagrado na Constituição Federal de 1988 como um dos fundamentos do nosso Estado Democrático e Social de Direito (art. $1^{\circ}$, inc. III, da Constituição da República). Busca claramente o apelante agregar valor monetário à vida humana, com o que não se pode compactuar. Com efeito, não é argumento para a improcedência o alto custo do fármaco (Agravo No 70057635914, Primeira Câmara Cível, Tribunal de Justiça do RS, Relator: Carlos Roberto Lofego Canibal, Julgado em 30/01/2014)

39 Alegar o alto custo do medicamento para o ente público se eximir de fornecer o tratamento solicitado pelo autor sobrepõe o interesse financeiro da administração ao direito à vida e à saúde daquele que necessita ser assistido (Agravo de Instrumento $\mathrm{N}^{\circ} 70062413752$, Primeira Câmara Cível, Tribunal de Justiça do RS, Relator: Sergio Luiz Grassi Beck, Julgado em 04/11/2014).

40 A Constituição Federal de 1988 enumera, dentre os direitos fundamentais de todo o cidadão, o direito à vida. E o legislador constituinte, ao garantir o direito à vida, garante não apenas o direito a manter-se vivo, mas o direito de dar a vida, de gerar um ser humano. ... A própria Carta Republicana tem na família a base da sociedade (art. 226) (Apelação e Reexame Necessário No 70061275285, Primeira Câmara Cível, Tribunal de Justiça do RS, Relator: Carlos Roberto Lofego Canibal, Julgado em 20/10/2014). 
based mainly on the right to life or to healthcare, but in the presumption of truthfulness of the prescription - does not matter if it is from a doctor linked to the public system or private one - once the doctor would be in good faith. ${ }^{41}$ The sovereignty of the medical prescription submitted by the plaintiff, more than avoiding any considerations of proofs that might sign on the contrary, it turns out to oversimplify the discussion. Such an argument is important because it is here where we can see a minor disagreement among the justices and judges: generally there is no disagreements on the first set of arguments, but here some justices have voted to allow the replacement of the drug or treatment required if the State is able to prove the existence of a similar treatment provided by the public policy. ${ }^{42}$ In other words, in general judges do not disagree in granting the treatment, but it is possible to see at least an incipient attempt to make citizens get medication effectively provided by the public policy - usually it is a generic drug with similar effect, but without the label of a big laboratory, so that costs are cheaper for the public system. Moreover, in this case, the government had bought the drugs in large quantities, what reduces the cost and allows greater care to the population with the same budget. ${ }^{43}$

The third argument works to rule out a fairly widespread position especially in the $90 \mathrm{~s}$, which understood social rights simply a program for the country, as a goal - and therefore not as an immediately applicable right. The argument is supported on the aforementioned first paragraph of Article 5 of the Constitution, understanding the right to healthcare as having immediate and unconditional applicability, regardless

41 - A medicação foi receitada com base em exame realizado na parte autora, sendo indicada para o seu caso específico, conforme atestado médico acostado, o que afasta os questionamentos sobre o tratamento ou mesmo a substituição. Ao depois, a afirmação do médico da parte autora não pode sucumbir diante de afirmação em abstrato de possibilidade de utilização de medicamento diverso. Impossibilidade de substituição.

- O fato de um dos medicamentos pleiteados ser considerado "off label" não impede a determinação de fornecimento pelos entes federados, uma vez que não paira qualquer dúvida de capacidade ou boa-fé sobre a confecção de laudos, atestados e receitas pelo médico assistente da parte (Apelação Cível No 70062488291, Vigésima Segunda Câmara Cível, de Justiça do RS, Relator: Marilene Bonzanini, Julgado em 12/11/2014).

42 A assistência farmacêutica por meio do SUS compreende os medicamentos essenciais (RENAME) e os medicamentos excepcionais constantes das listas elaboradas pelo Ministério da Saúde. Em princípio, não tem a pessoa direito de exigir do Poder Público medicamento que não consta do rol das listas elaboradas pelo SUS, balizadas pelas necessidades e disponibilidades orçamentárias. Hipótese em que o médico da autora admitiu a substituição de medicamento requerido por outro constante das listas públicas (Apelação Cível No 70040643017 , Vigésima Segunda Câmara Cível, Tribunal de Justiça do RS, Relator: Maria Isabel de Azevedo Souza, Julgado em 24/02/2011).

43 Linked tothis discussion, isthelobbyingby laboratoriesin the countryto implementitsnew drugs-sometimeswithoutproven effectiveness. 
any provision or organizations on laws, statutes, executive orders or regulations of public policies: that tiny phrase on the Constitution is enough. ${ }^{44}$ Looking it closely,we see that this is the strongest argument used when the discussion goes to the STF, precisely because they approach the issue as regards constitutional interpretation.

In paradigmatic case ${ }^{45}$ the STF, more than addressing the issue concerning with the immediate applicability of rights, also brought a fourth argument: the "right to hope." Although it is not written in the Constitution, this right was used as basis for granting experimental treatment in Cuba. The plaintiffs, as stated in the court decision, suffered from "a very rare disease called retinitis pigmentosa. It is a like glaucoma, because it leads to a progressive loss of vision. But, unlike glaucoma, in which there is surgery and appropriate treatment, in retinitis pigmentosa there is still no cure or treatments. The plaintiffs wanted the Ministry of Health to pay the trip to Havana." 46 Despite some Ministers ${ }^{47}$ have state that the system should not pay the trip, as there was no evidence of the effectiveness of the treatment, the case was upheld by majority. The reasoning referred to the already described arguments saying that "the economic aspect" 48 should not "prevail over the rights of citizens, considered the right to life and health," and that "the interpretation of the programmatic rule cannot turn it on an inconsequential constitutional promise," ${ }^{49}$ since it was immediately self-applicable, as provided by the first paragraph of the Article $5 .{ }^{50}$ What was new, however, appeared as follows: "in [the situation of] doubt between hope of success [of the treatment] and failure, I get the hope of success, of course. I think this [hope] is a right ... [and is] the function of the Supreme Court protect the dignity of human life. ${ }^{51}$

Understood the panorama and the arguments for court rulings granting treatments through judicial means, we believe it might be useful to now turn the attention to some existing data in Brazil on the issue. We have already mentioned the lack of quantitative research about the judgments

$44 \mathrm{The} \mathrm{TJ} / \mathrm{RS}$ has numerous precedents containing this statement "immediate and unconditional application of constitutional provision". See, for instance: TJ/RS, $21^{\mathrm{a}}$ Câmara Cível, Relator: Genaro José Baroni Borges, Apelação Cível n. 70052026465, j. 19/12/2012. TJ/RS, $21^{\text {a } ~ C a ̂ m a r a ~}$ Cível, Relator: Genaro José Baroni Borges, Apelação Cível n. 70052076130, j. 19/12/2012.

45 STF, RE 368564, Relator(a): Min. MENEZES DIREITO, Relator(a) p/ Acórdão: Min. MARCO AURÉLIO, Primeira Turma, julgado em 13/04/2011, DJe-153 DIVULG 09-08-2011 PUBLIC 10-08-2011 EMENT VOL-02563-01 PP-00064 RSJADV set., 2011, p. 51-68.

46 Min. Menezes Direito, RE 368564, 68.

47 Brazilian Justices at the STF are called "Minister."

48 Min. Marco Aurélio, RE 368564, 75.

49 Min. Marco Aurélio, RE 368564, 75. See also Min. Ayres Britto, RE 368564, 87.

50 Min. Ayres Britto, RE 368564, 88.

51 Min. Luiz Fux, RE 368564, 103. 
in the state of Rio Grande do Sul from where most of the above reported cases were extracted. However, corroborating our description, research conducted in the State of Rio de Janeiro between 2007 and 2008 concluded that "individual prescription, economic hypo-sufficiency and the urgency of the plaintiffs ... are the main grounds of judicial decisions." ${ }^{52}$

Yet, to illustrate the setting, especially regarding the elaboration of lists of medicines by the government as an instrument of public policy, it should be noted that, according to a research conducted in São Paulo between 2005 and 2009, 66.2\% of the medicines requested did not appear in court any public policy's official list. ${ }^{53}$ It can be concluded, therefore, that the lawsuits mostly seek to update the public policy, what may be a sign that the policy is lagged. The problem as we see, however, is not the claim to update the list - what could be required in a class action. The problem is the actual use of an individual demand for such proposes. In fact, the list happened to be updatedonly for those who file the lawsuit. This ends up relieving the political pressure over the Executive branch. However, instead of provide the right to everyone, or to those that are in a neediest situation, this actually provides the right just for those who are able to move the Judiciary.

Similarly, other quantitative research that aimed to "analyze the qualitative coverage ... for diseases listed in lawsuits" in São Paulo clearly shows that "there are limitations in terms of coverage," since some diseases listed in lawsuits are not included in any public policy. ${ }^{54}$ On the other hand, there are studies suggesting that $73 \%$ of the judicially granted medicines may have been replaced by drugs that actually are in the list ${ }^{55}$ and so that are provided in a free basis. From this one can infer there is at least some public policy for such diseases. In addition, the inference is strengthened when we see that the Ministry of Health's budget grew 3.2 times from 2002 to 2007 and the share of drug spending rose from $5.4 \%$ in 2002 to $10.7 \%$ in $2007 .{ }^{56}$ Finally, even more impressively, one can realize the growth of public investment in the segment (in this case, considering also the special

52 VENTURA, Miriam et al. "Judicialização da saúde, acesso à justiça e a efetividade do direito à saúde."Physis: Revista de Saúde Coletiva 20, n. 1 (2010): 77-100. Available at www.scielo.br.

53 MACEDO, Eloisa Israel de; LOPES, Luciane Cruz; BARBERATO-FILHO, Silvio. "A technical analysis of medicines request-related decision making in Brazilian courts." Revista Saúde Pública 45, n. 4 (2011): 706-13. Available at www.scielo.br/rsp 54 VIEIRA, Fabiola Sulpino; ZUCCHI, Paola. "Patient Lawsuits and Treatment Provision on the Brazilian National Health Service", 2009.

55 VIEIRA, Fabiola Sulpino; ZUCCHI, Paola. "Distortions to national drug policy caused by lawsuits in Brazil." Revista Saúde Pública 41, n. 2 (2007): 214-222.

56 VIEIRA, Fabiola Sulpino. "Ministry of Health's spending on drugs: program trends from 2002 to 2007."Revista Saúde Pública 43, n. 4 (2009): 674-681. 
expensive drugs for complex cases): “In 1993, the program distributed 15 pharmacological agents in 31 distinct presentations. This number increased to 109 agents in 243 presentations in 2009. Total Ministry of Health expenditure with medications was $\mathrm{R} \$ 1,410,181,600.74$ in 2007, almost twice the amount spent in 2000, R $\$ 684,975,404.43 .{ }^{\prime 57}$

Thus, even though there are flaws in the public healthcare service - especially when it is considered under the assumption that it should be universal - one also is able to see that there has been a substantially growth in public investments. There will always be at least some degree of insufficiency on the service, however. In this sense, it is nonetheless interesting the argument pointed out by Vieira when she demonstrates that to treat $25 \%$ of patients with chronic viral hepatitis type $\mathrm{C}$ - a disease that affects $1 \%$ of the Brazilian population - it would be necessary to invest $64 \%$ of the total Ministry of Health's expenditure (we mean, of the whole budget, not just of the drug supply line).So if $25 \%$ of possible cases were claimed in courts, two-thirds of the entire Brazilian health budget would have been spent to treat $0.25 \%$ of the population for just one disease. ${ }^{58}$

Moreover, it is worth mentioning that this framework exposes an increase in inequality, privileges and socioeconomic differences. It has been shown ${ }^{59}$ how regions with greater economic development of the country, such as south and southeast, concentrated $85 \%$ of court proceedings, even though its population represents $56.8 \%$ of the total. By their turn, the less prosperous regions, northeast and north, despite the fact that they count $36 \%$ of the population, concentrated only $7.5 \%$ of the lawsuits on the issue.

57 CARIAS, Claudia Mezleveckas; VIEIRA, Fabíola Sulpino; GIORDANO, Carlos V; Zucchi, Paola. "Exceptional circumstance drug dispensing: history and expenditures of the Brazilian Ministry of Health.” Revista Saúde Pública 45, n. 2 (2011): 233-240.

58 VIEIRA, Fabiola Sulpino. "Right to health litigations: a discussion on the observance of the principles of Brazil's Health System.” Revista Saúde Pública 42, n.2 (2008): 365-9. Available at www.scielo.br/rsp. A similar argument is made by the same author in another article where she shows that "to implement this therapeutic assistance policy to only $1 \%$ of the population and for only two diseases would be higher than the total of all levels of government spent on the set actions and health services" across the whole country. (FERRAZ, Octávio Luiz Motta; VIEIRA, Fabiola Sulpino. "Direito à saúde, recursos escassos e equidade: os riscos da interpretação judicial dominante.”Dados 52, n. 1 (2009): 223-251, p.238).

59 The data presentedare contained ina detailedstudy presented byFerrazand are based onperiodsbetween 2007and 2010 (FERRAZ, Octavio Luiz Motta. "Brazil, Health Inequalities, Rights and Courts." In: Litigating Health Rights: Can Courts Bring More Justice to Health? Edited by Alicia Ely Yamin and Siri Gloppen. Cambridge: Harvard University Press, 2011.). An interesting study, which reaches similar conclusions, but restrictedto the Stateof SãoPaulo,can be found atSILVA, Virgilio Afonso da; TERRAZAS, Fernanda Vargas. "Claiming the Right to Health in Brazilian Courts: the exclusion of the already excluded." Law and Social Inquiry, Forthcoming, 2008. Available at http://ssrn.com/abstract=1133620 or http://dx.doi.org/10.2139/ ssrn. 1133620 . 
The northeast region, with the lowest Human Development Index of the country, has one lawsuit for each 177,704 inhabitants; the South, with the highest HDI, has one for each 11,902 inhabitants.

This picture, we hope, shows that the reality is much more complex than the simplicity with which the courts are dealing with the issue.

\section{THE (NON-)JUDICIAL PROTECTION OF FUNDAMENTAL RIGHTS}

The intense healthcare protection by the courts in Brazil described above should make everyone - and especially Brazilian people - happy and above all relieved. After all, given the broad and unrestricted effectiveness that the courts have granted to the right to healthcare, it has practically become Brazilian "absolute right;" or, to use an (embarrassing) expression adopted by some judges, the right to health would be our "super-right" ${ }^{60}$ However, as we can advance, this is not exactly the case. Things are not so simple, and what appears to be protective fashion, in the end can actually generate perverse consequences.

This almost unrestricted effectiveness is commonly illustrated by the existence of a significant number of fancy judicial decisions that require the Executive branch in all three spheres of the federation to immediately provide individualized healthcare, including, as we have described, treatments with controversial essentiality and high cost drugs that still are experimental. When we refer how "generous" a court is, promptly one should recollect the kind of decision that provides acupuncture or equine therapy, for instance. Nevertheless, we shall refer something else, a detail that really shall relieve Brazilian people: courts do not even require the plaintiff to demonstrate or to proof that their claim was in fact denied by the public system in order to admit the lawsuit.

In procedure law, usually if " $A$ " requires " $B$ " the fulfillment of an obligation " $x$," " $A$ " carries the burden of demonstrating the occurrence of the failure in the obligation or, at least, she must to show the factual circumstances of in what manner "B" violated her obligation. Courts have said, though, that this condition is irrelevant. Meaning if " $A$ " needs the drug " $\mathrm{x}$ " she has the right to demand it directly at court and has not, therefore, any dutyto demonstrate that " $\mathrm{x}$ " was indeed denied by government or by the public system. This is the dominant understanding of the TJ/RS. ${ }^{61}$ Luckily (for court's everyday operation) a major part of

60 A quick research for the expression "super-right" at the TJ/RS Court's website provides us almost two thousand cases. As a instance, see: TJ/RS, Oitava Câmara Cível, Apelação Cível n. 70062642145, Relator: Luiz Felipe Brasil Santos, j.: 12/02/2015.

The expression, here, in the way we are using, has an ironic hue. Some judges take it seriously, though. 61 This understanding is really widespread in the court. As an instance, one might look some 
the population is still not aware they have this right to healthcare.

Judges should find the reality very strange. On the one hand, they both declare (claiming universality for similar cases) the existence of a "super-right" to healthcare, affirming that citizens can directly access the Judiciary as the first door, and they grant treatments far beyond those provided in public healthcare policies. But, on the other hand, they see huge lines of sick poor people looking for a simple bed in a hospital; they read news about lack of beds, doctors and staff; they lament publicly when emergency rooms close; as they also may hear that a friend of his family sold the car to pay the only healing hope for his son. Maybe then they should ask themselves whether the fundamental right to health applies onlyto the ones that fill lawsuits before the Judiciary. Or, are those who obey the administrative organization of health system fools?

A judge might reply: "It's not my fault if the citizen has not filed the lawsuit. I just rule the cases that I have in my court." But this would be a purely cynical reaction. And the cynicism would be to ignore deliberately - the fact that there are two abysmally different public ${ }^{62}$ healthcare systems in Brazil: one dealing with scarce resources, ${ }^{63}$

of this cases: TJ/RS, $2^{\text {a }}$ Câmara Cível, Relator: Arno Werlang, Apelação Cível n. 70051838977, j. 19.12.2012; TJ/RS, 7ª Câmara Cível, Relatora: Sandra Brisolara Medeiros, Apelação Cível n. 70052503265, j. 09/01/2013; TJ/RS, 22 ${ }^{\text {a }}$ Segunda Câmara Cível, Relator: Carlos Eduardo Zietlow Duro, Apelação Cível n. 70052645322, j. 21/12/2012; TJ/RS, $1^{\text {a }}$ Câmara Cível, Relator: Carlos Roberto Lofego Canibal, Apelação Cível n. 70052573797, j. 20/12/2012; TJ/RS, $21^{\text {a }}$ Câmara Cível, Relator: Francisco José Moesch, Agravo de Instrumento n. 70051494508, j. 12/12/2012.

São Paulo State Court follows the same token. See: TJ/SP, 6 ${ }^{\mathrm{a}}$ Câmara de Direito Público, Relator: Reinaldo Miluzzi, Apelação n. 1017443-98.2011.8.26.0506, j. 31/01/2013; TJ/ SP, $2^{\text {a }}$ Câmara de Direito Público, Relator: Claudio Augusto Pedrassi, Apelação n. 002209153.2011.8.26.0405, j. 15.01.2013.

Federal Courts also stand for the same understanding. For instance, TRF-4 ${ }^{\text {a }}$ Região, Quarta Turma, Relator: Luís Alberto D’Azevedo Aurvalle, Apelação n. 5000075-41.2011.404.7009, j. 22.01.2013.

Finally, ruling against his comprehension, at the $4^{\text {th }}$ Region Federal Court: TRF-4 ${ }^{\text {a }}$ Região, Relator: João Pedro Gebran Neto, Apelação n. 5005791-21.2012.404.7201, j. 20/11/2012

62 Perhaps it would be appropriate to say there are three healthcare systems in Brazil, two public and a private one: The public ones we are referring here in this paper. In the private system, usually people pay monthly for a healthcare company. In this system, the subscribers use other doors in hospitals, other doctors, wait in other lines, and so on. It is a completely different (and usually better) service. Finally, one also can pay her doctor directly when necessary, with no healthcare system at all. This last one happens to be the most expensive.

63 On the cost of rights, Holmes and Sunstein argue: "Rights are familiarly described as inviolable, peremptory, and conclusive. But these are plainly rhetorical flourishes. Nothing that costs money can be an absolute. No right whose enforcement presupposes a selective expenditure of taxpayer contributions can, at the end of the day, be protected unilaterally by the judiciary without regard to budgetary consequences for which other branches of government bear ultimate responsibility." (HOLMES, Stephen; SUNSTEIN, Cass R., The Cost of Rights: 
which depends on organization and planning and is, thus, "flawed;" and another one perfect, immediate and which coverage is better than any health plan (we dare say) in the world. In simple words: the same Constitution, the same bill of rights, is being applying in Brazil in profoundly different manners. Government (i.e. Executive branches) applies the right to healthcare as a public policy: itcarries out thepublic service bydesigningpoliciesin light of theConstitutional guidelines, prioritizing somemost urgentareaindetriment of others. In this sense, policies involve, by definition, disjunctive choices. On the other side, judges, as already pointed out, apply the right to healthcare as an individual subjective right, as something that the state shall provide to any individual regardless of social policies, public choices or any other considerations for the community. It is, therefore, an individualistic and not a social - approach. ${ }^{64}$

We shall remind that Brazilian Constitution's Article 196 refers that health "shall be guaranteed by means of social and economic policies." In the same token, Article 198 goes further and provides the establishment of a decentralized and hierarchical healthcare system (which is regulated by laws, statutes and executive orders). All this regulation establishes competences and procedures between the spheres of the federation, and even establishes how resources and budgets should be used. However, what judges really take into account is the provision saying that healthcare is a fundamental right and the provision saying the guarantee of fundamental rights has immediate application. And then, the understanding that any judge should recognize them in a simple decision-making operation even in lawsuits filled by individuals makes sense in their own terms. It is because, in their view, the Constitution is not just an empty program, but a document whose normativity and effectiveness citizen reaches through courts.

In brief lines, this is the synthesis of the constitutional culture that frames the thought that justifies judicial effectiveness of the fundamental right to health in individual cases moved against the State.

\section{Constitutional Principles, Disagreement and Models of Constitutionalism}

Based in our description so far, it would be natural labeling Brazilian judges as activists. However,this diagnosis may be refined. In general, activism, and judicial activism in special, is the deliberate action of ruling in favor of her cause; what means, she rules in order to implement the political / ethical / moral path she deems just, even if this ruling go against some statute or law establishing a different standard.

why liberty depends on taxes. New York: North \& Co., 1999, p. 97).

64 This argument will be further developed latter on in this paper. 
Tom Campbell, in an acid argument, considers the activist judge as a betrayer: legal system provides guarantees to the judge, ensures irremovability, and facilitates independence, and so on, in order to allow impartiality and equality under the law. ${ }^{65}$ But, then, judges respond with partiality. The word betrayal is strong, but perhaps adequate. A partial judge has consciously abandoned the law.

Judicial activism in general is an isolated position, which is limited to the point of view of ethics of the judicial function. There are things that a judge should do; and others, such as to promote her own cause despite the frames given by a democratic system, that a judge should not do. Not surprisingly, the critical description of an activist judge simply says it is a tyrant. The issue of unrestricted effectiveness of the right to healthcare is not just a simple desire to give maximum effect to this right, though. In other words, we are approaching here not the individual judges, but a widespread mentality. As we did above, a jurist committed to the description of the Brazilian legal system in these matters would have to simply state: "that's how things work around here." It is, therefore, an established practice, sealed by the Supreme Court and, as in the examples we have cited, carried out (with little self-restraint) by ordinary jurisdiction. Usually descriptions and analysis rests on this dominant understanding, in Brazilian legal practice, of the judicial protection of fundamental rights. What we propose for this section is some exploration on the reverse: the non-dominant understanding.

The dominant theoretical area in Brazilian law, which has a decisive influence on how one interprets the effectiveness of the Constitution and fundamental rights, is the post-positivist ideas or neoconstitutionalism. ${ }^{66}$ Nomenclatures, though, should not distract us, since any of these labels have reduced explanatory power, mainly when one consider the number of thinkers worldwide who identify themselves with this label. The crucial point, however, is to stress that the dominant standpoint is based on a strong sense of rights (usually formulated as "principles") which become the starting and the arrival point of the application of the law. ${ }^{67}$ In this context, the judicial function gains a

65 CAMPBELL, Tom. Prescriptive Legal Positivism: Law, Rights and Democracy. London: UCL Press, 2004, p. 117.

66 A worthy account of this model is offered by Riccardo Guastini, when he approaches the "constitutionalization of law". Some features listed by him include a rigid Constitution; legal and judicial assurance of the Constitution; binding (normative) force of the Constitution; "over-interpretation" of the Constitution; direct application of Constitutional norms; consistent interpretation of laws through the Constitution; Constitution influence on political relations. See GUASTINI, Riccardo. La "constitucionalización” del ordenamiento jurídico: el caso italiano. In: CARBONELL, Miguel (Ed.). Neoconstitucionalismo(s). Madrid: Trotta, 2003 (pp. 49/74), pp. 51-58.

67 This sentence deserves a better clarification. Principles would be the justification, the 
much greater weight: judges not only have the task to rule conflicts, but to judge them giving maximum effectiveness to fundamental rights. In short, the idea of "effecting" the Constitution is the same to say judicially effecting it.

This way to see the law ignores - and in Brazil this news has not yet arrived; and if it has, definitely it is not on lawyers' thoughts - the very existence of disagreement on the fundamental rights' meaning and scope ${ }^{68}$ Consider, for instance, the principle of equality: A citizen " $A$ " and a citizen " $\mathrm{B}$ " may accept with confidence the normativity of the right to equality, i.e. they can identify it as a "ought to be". However, nothing guarantees that both possess identical conceptions of what it means to violate or to carry out the principle of equality ${ }^{69}$ Rather, in a pluralistic society - such as Brazil - the normal and expected is that people disagree on such matters, which are based on political opinions and concrete notions of freedom, equality, solidarity, morality, dignity, etc. Legal principles, such as the ones listed here, hold an open meaning, lacking certainty and clarity.

Thus the idea that judges must carry out and maximize what the charter of fundamental rights prescribes usually does not take seriously the fact of pluralism and the fact of disagreement. Those are ignored political realities. Moreover, a judge seeking to resolve any conflict between the citizen "A" and the citizen "B" simply cannot rely solely on the right to equality, since in abstract both sides agree with this principle. ${ }^{70}$ It is a common standard for the parties in conflict. To rule the case, the judge must necessarily engage in the development of a concrete political conception of the principle of equality, so that this concretion is, now, able to settle the conflict.

We are not even saying that there cannot be a good set of reasons to build an institutional arrangement in which judges have that kind of power - this is contentious and there is ample literature on the subject. ${ }^{71}$ What we are actually contending is the absence in Brazil of clear and self-aware reason for that doctrine: it is just accepted as the only and

substance, i.e. the reflective dimension of the rules and ultimately of the law. One reflects on a rule from a set of principles. In this sense it is a starting point. But it becomes arrival point when it leaves the reflective dimension and passes to the dimension of adjudicator of the conflict.

68 Waldron's Law and Disagreement is mandatory on this issue (WALDRON, Jeremy. Law and Disagreement. Oxford and New York: Oxford University Press, 1999).

69 See ATRIA, Fernando, ATRIA, Fernando. "El Derecho y la contingencia de lo político", Doxa, n. 10, 1991 (pp. 319-345).

70 ATRIA, Fernando. "El Derecho y la contingencia de lo político", p. 332.

71 Waldronhimselfno longercriticizes thejudicial reviewas presentedinLaw andDisagreement. $\mathrm{He}$ has come to acceptthat the absence orpresenceofjudicial reviewmust take into accountcontextualreasons. See WALDRON, Jeremy. "The Core of the Case Against Judicial Review."The Yale Law Journal, 115: 1346, 2006. 
obvious option. The silence of other institutional alternatives leads us to think that maybe there are also good reasons to prefer another type of arrangement or, at least, the raise some criticisms on the mainstream.

In any case, what does the legislative do but exactly what we point out above referring to judges: "engage in the development of a concrete political conception of the general principle?" When, for instance, a statute passed by the legislative branch grant half price tickets in cultural shows to students or when a statute provides specific rights to persons with disabilities, are not legislators concreting, by certain means, the abstractness of the principles? And if these statutes are enacted in a country with a list of fundamental rights, it is not the case that the statute is actually accomplishing such rights, that is, avoiding the principles of being "empty promises?"

What does not inhabit the thought of Brazilian lawyers, and especially those who apply the law, is the clear sense that the legislative also interprets, applies and carries out the Constitution. The existence of a practical and doctrinal state-of-mind which excessively positions in the judiciary the field to resolve moral and political disagreements under the cloak of "legal interpretation," in fact does not adequately consider the legislative as an interpreter of the Constitution. ${ }^{72}$

Considering legislators as a constitutional interpreter and as a figure, at least in principle, legitimate to define the content and scope of fundamental rights has shed some light to what have been called "weak constitutionalism" or weak-form of judicial review. For Mark Tushnet, the weak version of judicial reviewis not only the recognition of the fact of disagreement, but also the acknowledgement that different branches (executive, legislative and judicial) may provide reasonable and competing interpretations on fundamental rights. In his account, it also recognizes that there is no reason to prevail, a priori, one of these interpretations as definitive, especially the judicial interpretation. The idea of prevalence of judicial ruling on the meanings of the Constitution is typical of the "strong constitutionalism", or strong-form of judicial review."

Some examples may show better the point. Let us see, for instance, Canadian Constitution: in Canada there is a Bill of Rights (Canadian Charter of Rights and Freedoms) and there is a Supreme Court with powers to control the constitutionality of laws. However, there is also a "notwithstanding" clause, by which the legislative can, provided they fulfill the requirements contained in the Canadian Bill of Rights, enforce a legal provision even if the Supreme Court considers that it is against

72 As a matter of fact, it must be said Brazilian judges are chosen to the position through a competitive and difficult public test. Thus, the criterion is completely technical. Political influences do not play a role. After two years, they reach lifelong tenure.

73 TUSHNET, Mark. Weak Courts, Strong Rights: judicial review and social welfare rights in comparative constitutional law. Princeton and Oxford: Princeton University Press, 2008, p. 228. 
fundamental rights established in the Charter (the notwithstanding clause covers only the rights included in section 2 and between sections 7 and 15). Another example is the Constitution of Australia, since - despite rigid - does not incorporating a Bill of Rights. The Dutch Constitution, by its turn, expressly prohibits judicial review of legislation. ${ }^{74}$

Although it is not our objective to evaluate in details the experience of these countries, it should be noted that each of these arrangements imply consequences that sometimes can make strong a model that, in theory, would be weak, and by the same token some arrangements may turn in weak a seemingly strong model. The UK is commonly presented as an example of "weak constitutionalism," even after the advent of the Human Rights Act(1998). This is because, although British judges can perform the control of the legislation in the light of the European Convention on Human Rights (ECHR), they do not have the authority to declare the invalidity of the law, but only its "incompatibility," leaving to the Parliament the final word ${ }^{75}$ However, the Human Rights Act also provides (section 3.1) that: "so far as it is possible to do so, primary legislation and subordinate legislation must be read and given effect in a way which is compatible with the Convention rights." Some believe that this norm, in practice, may grant more power to the British judiciary, turning it stronger than some countries with strong judicial review model. ${ }^{76}$

In any case, we shall stress these countries have an institutional history significantly distant from the judicial protection of fundamental rights. Their constitutional history is far from what we called above "direct application of fundamental rights" through courts, a kind of mantra of the Brazilian Constitutional Law. They serve, here, not just to show, by opposition, Brazilian legal practice regarding judicial application of rights, but also to set a different perspective on the issue.

This character of the Brazilian understanding can be explained in common sense terms: if the Constitution establishes principles of equality, freedom, dignity; and if it also provides that "health is a right of all," then give to the judiciary power to enforce these commandments in each individual case can only be a "good thing." This setting gives to law an appearance that it is committed with "justice." The world with fundamental rights can only be a better world. And if this is so, it also

\footnotetext{
74 See BAYÓN, Juan Carlos. "Democracia y derechos: problemas de fundamentación del constitucionalismo". In:CARBONELL, Miguel y JARAMILLO, Leonardo García (coord.) El canon neoconstitucional. Madrid: Trotta, 2010.

75 For this topic, see KAVANAGH, Aileen. Constitutional Review under the UK Human Rights Act. Cambridge: Cambridge University Press, 2009.

76 As an instance, see HIEBERT, Jane L. "Governing like judges?" In: CAMPBELL, Tom, EWING, K.D and TOMKINS, Adam (Eds.). The Legal Protection of Human Rights:skeptical essays. Oxford: Oxford University Press, 2011, p. 54.
} 
seems a good idea to judicially protect those rights.

We are trying to say maybe it is not. Definitely from Brazilian lawyers' perspective it is, but perhaps raising some doubts on the "constitutionalism of rights" could actually (paradoxically) help to grant more rights. What do places like the UK, Canada, Australia, Netherlands, New Zealand, Finland, Denmark, Sweden, have in common? These are countries that have no enthusiasm for the constitutional and judicial protection of fundamental rights. ${ }^{77}$ They are countries that retain substantially the modern idea of parliamentary sovereignty. Finally, they have a seated culture of individual and social rights. In short: their rights are weak in legal-judicial sense but are strong (much more than in Brazil, surely) in the political sense, in terms of distribution and allocation of goods and resources.

Of course one could raise the fact that many countries that have a strong constitutionalism (Germany is a paradigmatic example) also have high levels of respect and realization of social rights. No doubt. We do not dispute it. However, in such cases, one also must ask whether this state of affairs arise from the constitutionalization of rights (and its judicial protection) or from the community's political commitment to building a welfare state. Examples of weak judicial review do not point out that strong judicial review countries in general are countries with unsatisfactory achievement of economic and social rights. But these examples indicate, at least, that the judicial protection of fundamental rights - especially social rights - is not a decisive element for the social promotion of these rights: it is not a necessary condition.

Hirschl and Rosevar refer, for example, the cash transfer program carried out by the Brazilian government since 2003 ("Bolsa Família"). The program, according to the authors, had a significant impact on poverty reduction in the country. They conclude that this improvement in social indicators took place directly from government policies of a left government, usually more committed to social rights, and not from a constitutional reform or from the active role of the courts. ${ }^{78}$ Although this example requires some further research, the essence of the argument seems satisfactory: if the aim is to promote social equality and achieving social rights, there is relevant evidence that electing a government committed to this purpose is more effective than relying on the "juristocracy" placed in courts the task to maximize the fundamental rights.

77 HIRSCHL, Ran and ROSEVAR, Evan. Constitutional Law Meets Comparative Politics: socio-economic rights and political realities. In: CAMPBELL, Tom, EWING, K.D and TOMKINS, Adam (Eds.). The Legal Protection of Human Rights:skeptical essays. Oxford: Oxford University Press, 2011, p. 213.

78 HIRSCHL, Ran and ROSEVAR, Evan. Constitutional Law Meets Comparative Politics, 2011, p. 214. 
This argument brings to the realm of politics not only the resolution of moral disagreements, but also the resolution of disagreements about the best way to (re)distribute resources. But, then, politics needs to work. If this is so, the attention of Brazilian jurists should turn less to the catalog of fundamental rights and more to the formal part of the Constitution, which involves the division of powers, federalism, share of duties and responsibilities, etc. It is paradoxical, but Tushnet may have a point already in the title of his book Weak Courts, Strong Rights: in the name of fundamental rights, it is worth looking less for fundamental rights, as a judicial term. In the name of fundamental rights, rather than focusing energies in discuss how to judicially carry out these rights - the issue that grasps most legal publications in Brazil - it would be better to question which institutional role should play the judges so then the whole country can be closer to the "promises" stated in the Constitution.

\section{How could the judiciary, then, protect rights?}

The judicial application of the right to health in Brazil does seem to be a sui generis case. The strong judicial review is characterized in general by the existence of a formal procedure for judicial review, a catalog of fundamental rights and the constitutional jurisdiction authority to interpret the Constitution; or by a combination of elements that give judges more power to give concreteness to the constitutional principles. But when it comes to economic and social rights, even countries of strong constitutionalism routinely engage in significant deference to public policies implemented by the government (in the broad sense). The idea that every citizen has an individual right to claim a health treatment regardless of the community and without the need to demonstrate that the public service has first actually failed in providing the care is something that probably would surprise lawyers and political scientists around the globe: how is so that nobody thought this before? If a singular judge can save us with a pen, the most complex political and social problems are solved!

But, if judges are not going to solve all social matters with individual rulings; which is the judicial branch's role?

Tushnet criticizes American constitutionalists for they cannot see that the judiciary can indeed play a role in the protection of social rights. But what motivates Tushnet's criticism is the fact that his fellows whenever reject the relationship between judges and social rights are actually thinking in terms of strong-form of judicial review, ${ }^{79}$ that is, in a way to directly guarantee the right to the citizen through courts,

79 TUSHNET, Mark. Weak Courts, Strong Rights, 2008, p. 247. 
as in Brazil, what would sound unacceptable to American mainstream. Tushnet's argument do not even touches the transmutation of a social right in an individual one, as we are trying to stress throughout this paper. He only argues that mechanisms of weak-form of judicial review may be useful to assist in the achievement of economic and social rights: courts do not need to be (always) strong.

In the area of social rights, the Constitution of South Africa took a realistic path. Section 27 states: "The state must take reasonable legislative and other measures, within its available resources, to achieve the progressive realization of each of these rights" ${ }^{80}$ Therefore, it is required from the government the implementation of reasonable measures to progressively achievethe realization of social rights. This view, in fact, considers the scarcity of resources and the very reality. There is no magic: the judicial review, even controversial, can focus on the reasonableness of public policy, which involves, by definition, a focus on promoting general social rights.

In the Constitution of Ireland, social rights are part of the "principles of social policy" and the application of these principles "shall not be cognizable by any Court under any of the Provisions of this Constitution." ${ }^{81}$ Social rights are here non-justiciable; however, they may be the subject of a judicial declaration that demonstrates Parliament and Executive have failed in the realization of public policy. Legally, this is a weak measure, but maybe able to politically impact society and influence the agenda of the branches responsible for electing the means to effect social rights and, mainly, to influence the people themselves.

In its turn, the Constitution of Spain has also posited such rights in the realm of the "governing principles of economic and social policy." However, their Constitutional Court recently, and in the context of the government's austerity policies, suspended the rule restricting access to public health care to illegal immigrants. The Court found that the government was not able to prove the financial impact which could justify the damage to public health. Here, again, is the public policy what is under review, in a general fashion, and not specific individual cases. ${ }^{82}$

In light of these cases, we can already observe certain range. On the one hand, is the complete absence of the judiciary with regard to social rights - whether it comes to the public policy as a whole, or to individual and particular cases. In the center, there are mechanisms of

80 Tushnetgives the exampleof judicial review, in South Africa, onpublic policies forhousing. Seehis commenton the caseSouth Africav. GrootboominTUSHNET, Mark. Weak Courts, Strong Rights, 2008, pp. 242-243.

81 TUSHNET, Mark. Weak Courts, Strong Rights, 2008, pp. 239-40.

82 Tribunal Constitucional de España, Auto 114/2014, Recurso de Inconstitucionalidad 70892013, j. 08.04.2014. 
weak judicial review, which can provide some hints to the role judiciary branch can have. And, on the other hand, there is the Brazilian legal practice, which understands the right to healthcare as an individual right, creating a unique health system for accessing "justice." 83 In the same way Tushnet would like their American colleagues observe the experience of weak constitutionalism, we also would like to see Brazilian constitutional theory adopting - or at least engaging in debates with - a skeptical attitude towards strong judicial review and, in particular, with the mantra of the direct application of fundamental rights.

\section{Mega-POLITICS AND THE BRAZILIAN POLITICAL IDENTITY}

What are the meanings and consequences of the existence of two systems through which social rights are implemented in Brazil? Such a course of action increases or decreases the implementation of social rights? What is the character of the Brazilian Constitution and political system, given the way in which social rights are implemented and understood by the three powers? To answer questions like these, we have tried so far to raise a double criticism, since legal and political. Now, we want to change from a descriptive account to an argumentative one.

The criticism from the legal standpointhas at least three elements to be highlighted, all related to what we call legal reasoning problem: the way of reasoning in these cases, in our view, is no longer legal. This is because, first, it is treating a collective (or social) concept under the individual point of view and with individualistic framework. It is what Atria calls "de-socialization" 84 of social rights. In his account, it is just by de-socializing the social right that one can fully comprehend an individual lawsuit filled out in terms of individual subjective right: "what reaches the Court is not a social right, it cannot be a social right, but an individual claim, which expresses not the idea of a higher form of community but actually express a denial of it: the plaintiff's claiming for his own interest to be attended even at the expenses of all the other's concerns." ${ }^{85}$ That is, the right to health, how reported here, is seen from an individualistic perspective and not from a social one. ${ }^{86}$ Social rights'

83 Here there is a double meaning in Portuguese: "accessing justice" means both accessing justice itself, as a substantive fair share; and it also means to reach the judiciary branch, that is, to stand for lawsuits in order to claim for rights. Between the lines we may see what is said: it is just though the judiciary that justice is achieved.

84 ATRIA, Fernando. “Existen Derechos Sociales?” Discussiones: Derechos Sociales n. 4 (2004): $15-59$.

85 ATRIA, Fernando. “¿Existen Derechos Sociales?”, 2004, p. 52. This is our free translation from the original in Spanish.

86 Silva refers to a research which studying cases of granting drug in individual lawsuits found that in $93 \%$ of the decisions judges used the argument that the right to health was an 
collective and relational feature is lost, and the right is transformed into a consideration that is due to the individual apart from the rest of society - for this reason Lopes believes that, in addition to a desocialization, through an individual judicialization of social rights we are also facing a "de-politicization." ${ }^{87}$

The legal reasoning is not threatened only because the understanding of a collective right is made in individual terms. Secondly, there also is a confusion regarding the dogmatic of fundamental rights. In general, the Brazilian legal community accepts the distinction between legal rules and legal principles and the use of balancing method to apply these principles. Indeed, this has been the theoretical basis to support the justiciability of social rights. The balancing doctrine suffers many objections, but even if one accepts it, she must conclude that it actually does not support the Brazilian judicial attitude in implementing the right to health. To balance means checking how heavy each principle at stake is in relation to each other, so that in the end, the judge can figure out a rule that will guide the solution of the given case ${ }^{88}$ In other words, it is a kind of comparison between two principles. The procedure, thus, depends on the concrete facts involved in the case (i.e. it needs proof and evidence); but more importantly, it also depends on a serious approach to the tension between the eagerness to implement the social right - which is on one side - and the respect to the general equality and the legislative democratic decisions - which are on the other side. If judges treat the right to health as a legal rule of immediate application, as if the Constitution had already said everything in terms of the right to health, they are not balancing anything: there is no tension and consequently there is nothing to be compared with, since they just consider one side of the scale.

Finally, thirdly, the only way to describe the reasoning used in these cases is to call it, as does Lopes, "charitable reasoning." ${ }^{\circ}$ It is understood as casuistic, concrete, exceptional, made for the good of the individual that receives it; ${ }^{90}$ yet, precisely because of its exceptionality,

individual kind of right. He also concluded that, in general, judges were not concerned with knowing the existence of a possible public policy for the disease discussed in the case (SILVA, Virgílio Afonso da. "O Judiciário e as políticas públicas: entre transformação social e obstáculo à realização dos direitos sociais.”, 2008, p. 595).

87 LOPES, José Reinaldo de Lima. "Brazilian Courts and Social Rights: A Case Study Revisited", 2006, p. 205.

88 ALEXY, Robert. Teoria dos Direitos Fundamentais. Trad. Virgílio Afonso da Silva. São Paulo: Malheiros, 2008, p. 97.

89 LOPES, José Reinaldo de Lima. “Em torno da 'Reserva do Possível.”Direitos Fundamentais: Orçamento e Reserva do Possível, edited by Ingo Wolfgang Sarlet, Luciano Benetti Timm, 15573. Porto Alegre: Livraria do Advogado, 2008, p. 171.

90 More than one author emphasizes pity that judges feel in individual cases. Pity that sometimes can be realized in the judges' ruling justification itself (LOPES, José Reinaldo de Lima. "Brazilian Courts and Social Rights: A Case Study Revisited", 2006, p. 206;Tessler, 
it cannot be universalized. Universality, though, is one of the features that show the justice of a decision in terms of consistency. Legal rulings under a democratic regime should not be based on judgments ad hoc.

Charity's casuistry generates a lack in the public debate: no one is politically responsible or accountable for the realization of social rights in a systematic way. Here it is the criticism we have called political. If criticism in legal terms is to say that the way in which judicial rulings have been handed down in this area do not hold themselves even within the legal doctrine that firstly based them; political criticism is to say that such a course of action is contrary to the democratic national identity, generating a draining from the public debate and, in the end, contributing to the deterioration of democracy: instead of adding more people in public space, in fact it only strengthens a "juristocracy" distanced from the people.It is not the people who make the decisions on redistributive issues, but a gowned aristocracy devoid of political responsibility in the public sphere. Judges, at least in Brazil, have no incentive to take on responsibilities in terms of resource allocation or public justification in general and political terms. ${ }^{91}$

If social rights are understood as necessary for democracy's improvement - since they give conditions for a lot of people fall within the public space - so decisions about public policies indeed affect the national identity. Here Hirschl's division between "judicialization from below" and "mega-politics" referred in the beginning merges: the implementation of social rights, therefore, is not just a debate on budget, but it is also a discussion of the political identity of a country, it is a discussion on who counts as people, who takes the decisions, who are accountable for these decisions and, finally, who can exercise control over such decisions.

This becomes clearer when one considers social rights through the prism of "distributive justice." Since Aristotle distributive justice is understood as a criterion to justify the unequal treatment in order to achieve justice. ${ }^{92}$ So, it is not a simple numerical equality, which is

Marga Inge Barth. "Medicina baseada em evidências e o direito à saúde."Revista de Doutrina da $4^{a}$ Região 29 (Abr. 2009). Available at http:/www.revistadoutrina.trf4.jus.br/artigos/ edicao029/marga tessler.html).

91 As stressed earlier, Brazilian judges, except for the STF which are selected by Presidential indication and approved by the Congress, have lifelong tenure and are selected through public competition on legal knowledge LOPES, José Reinaldo de Lima. "Brazilian Courts and Social Rights: A Case Study Revisited", 2006, pp. 186-187). So, they are actually approved to the position through a "technical" test in which political considerations do not play a role.

92 ARISTOTLE. "Nicomachean Ethics," Book V, 2, 1130b30 and Book V, 3, 1131a25.In:The Complete Works of Aristotle, edited by Jonathan Barnes, 1729-1867. Princeton: Bollingen Series LXXI 2 , Volume Two. Sixth Printing, 1995. 
carried out by "rectificatory justice" that considers parties as equals. ${ }^{93}$ Distributive justice, then, demands a predicate through which the distribution can be made unevenly in order to reach justice.

The traditional, common sense, judiciary's role is to resolve rectificatory conflicts: the description of the judiciary as the branch that holds the task of judging conflicts between individuals in terms of commutative justice, in their bilateral relationships, is trivial. In this case, the conflict is not political in the sense used here in this paper, insofar as it just involves two individuals, in their own personal interests, within their individuality and without a greater relationship to public goods. ${ }^{94}$ However, the reasoning is different when it comes to judging cases of distribution (or in this case would be better to say re-distribution) of public goods. If redistribution requires a predicate, it is always related to the whole which is distributed. The whole (i.e. what is distributed) is always kept in the horizon. In the case of social rights, the predicate is the need: to each citizen some part of the public goods in accordance with their social need. It shall be noticed that the whole (public goods), in this narrative, are always kept in consideration: citizens receive some part of the concrete whole and not some part of any vague infinite right. In other words, redistribution is made with reference to the whole, in order to increase public involvement in the public sphere. It is different in the rectification case, in which the decision is made with no predicate: is equality for equality in the crude sense, without any regard for the whole, since there is no whole but only the relationship between the parties involved in the specific conflict. Commutation and distribution follow different standards.

Redistribution is the political quarrel par excellence. It is representative of the community's internal debate performed in order to reach decisions on what to do with the public goods: in this sense it is, then, "mega-politics - matters of outright and utmost political significance that often define and divide whole politics." 95 The claim for social rights appears, therefore, not as the conflict with another private, in relation to particular goods, but as the conflict - or demand - filled

93 ARISTOTLE, "Nicomachean Ethics,” Book V, 4, 1132a5.

94 LOPES, José Reinaldo de Lima. "Brazilian Courts and Social Rights: A Case Study Revisited", 2006, pp. 191-196;LOPES, José Reinaldo de Lima. "Judiciário, democracia, políticas públicas.” In Revista de Informação Legislativa 31, n. 122 (Mai/Jul, 1994): 255265. 255-7; BORGES, Danielle da Costa Leite; UGÁ, Maria Alicia Dominguez. "As Ações Individuais para o Fornecimento de Medicamentos no âmbito do SUS: Características dos Conflitos e Limites para a Atuação Judicial.”Revista de Direito Sanitário 10, n. 1 (Mar./Jul. 2009): 13-38, pp. 25-29. Available at www.scielo.br 95 HIRSCHL, Ran. "The Judicialization of Mega-Politics and the Rise of Political Courts." Annual Review of Political Science 11 (2008), p. 2. Available at SSRN: http://ssrn.com/ abstract $=1138008$ 
out in relation to the whole social body. ${ }^{96}$

A recurring argument between those who have a favorable view to the justiciability of social rights is precisely articulated in terms of reducing inequality. The argument is articulated as if what was actually at stake with the judicialization was a questioning on the form of how redistribution of public goods is made. ${ }^{97}$ In other words, judicialization is presented as a progressive way to reduce inequality: encumber the rich to provide basic services to the poor. ${ }^{98}$ Such an argument, however, seems fallacious insofar as judicial decisions are carried out primarily with the budget that would otherwise be used in that same area, i.e. in healthcare, but to benefit a larger group of poor people, and not just a specific person that could reach courts. The predicate - the criterion of distribution - is overlooked since the judicial order is not considering all other citizens, but just that one whose have filled out the lawsuit. Therefore, the judicialization does not increase redistribution, and does not generate a clash between "rich and poor," but only foster an internal fight between the poor. ${ }^{99}$

The political question saw from the point of view of redistributive justice is how to reduce inequality; or, in a political statement, is how encumber richer and favor poorer in order to meet the goal of reducing inequalities. The ultimate end - reducing inequality through healthcare provision - is defined by the Constitution, and it seems to be no major disagreements on this. ${ }^{100}$ The question, then, turns to a consideration on the means, and not on the ends. Social rights are for everyone, but the

96 LOPES, José Reinaldo de Lima. "Judiciário, democracia, políticas públicas, 1994, pp. 255 262; LOPES, José Reinaldo de Lima. "Em torno da 'Reserva do Possível”, 2008, pp. 155-159; LOPES, José Reinaldo de Lima. "Direito Subjetivo e Direitos Sociais: o dilema do Judiciário no Estado Social de Direito", 2002, pp. 124-129; LOPES, José Reinaldo de Lima. "Brazilian Courts and Social Rights: A Case Study Revisited", 2006, pp. 191-196.

97 LOPES, José Reinaldo de Lima. "Direito Subjetivo e Direitos Sociais: o dilema do Judiciário no Estado Social de Direito”, 2002, pp. 138-40.

98 VENTURA, Miriam et al. "Judicialização da saúde, acesso à justiça e a efetividade do direito à saúde", 2010, p. 91.

99 LOPES, José Reinaldo de Lima. "Judiciário, democracia, políticas públicas, 1994, pp. $257-$ 8; LOPES, José Reinaldo de Lima. "Direito Subjetivo e Direitos Sociais: o dilema do Judiciário no Estado Social de Direito”, 2002, pp. 138-40.

Not to mention another aspect that could be used against this alleged progressive standpoint: judiciary may be conservative rather than progressive, working as an institution to preserve ancient privileges (Lopes, "Brazilian Courts," 194; LOPES, José Reinaldo de Lima. "Em torno da 'Reserva do Possível”, 2008, pp. 140-141). Hirschl presents several cases in which important social changes were barred by courts worldwide (HIRSCHL, Ran. "The Judicialization of Mega-Politics and the Rise of Political Courts", 2008)

100 VENTURA, Miriam et al. "Judicialização da saúde, acesso à justiça e a efetividade do direito à saúde", 2010, p. 84. 
Constitution does not say who first, ${ }^{101}$ neither does it say how: it just states the ideal, but not the path to reach it. Thus, the political question is how to implement this goal and for whom first. It is a question on the means. ${ }^{102}$

When we stress the political hue of redistribution being a performance in public space, we can be better understood if one recollects the idea of the political outlined by Hannah Arendt in her book "On Revolution," mainly her emphasis on the "public space" as the field where political action is possible. ${ }^{103}$ Arendt's emphasis on the formal aspect of politics - and the absence of references to the substance of the action - is what allows the existence of pluralism. However, when the tough decisions - those that can cause conflict about the redistribution of resources between rich and poor - are removed from the public space and allocated in courts (which in this case cannot be considered a "public space" because they do not allow "political action"), the acceptance among different social groups is hampered. The social bond begins to break: there is no more understanding of how to distribute public goods, but there are just demands and conflicts about what to receive (as an individualright, we shall underline). The grammar is not anymore about $u s$; but it is just about me. Once more, the connection between social rights and mega-politics is seen.

Redistributing hurts and pains: those in a more advantaged position do not like redistribute. And to keep the bonds in such society redistribution in a way must be accepted as legitimate by those who have more. This will only happen in the public sphere, i.e. in politics, and not just by the desire of a group of "technician" lawyers and judges pretending that political issues are legal ones. Doing redistribution in the particular case (lawsuits, for instance), without attacking the issue as a whole, only generates a fake-redistribution among the disadvantaged layers, having the side effect of ensuring the maintenance of the status quo for those more favored, who, then, do not participate in the redistribution at all.

The rulers (politicians, not judges) - who, in principle, are accountable before the people that elect them - do not feel, and are no longer seen by the population, as responsible for the operation of the system. In fact, they end up accepting the taking of their competences by the judiciary. ${ }^{104}$ In turn, the judges also are not politically accountable

101 LOPES, José Reinaldo de Lima. "Brazilian Courts and Social Rights: A Case Study Revisited", 2006, p. 204.

102 The political debate can also be on the ends, of course - in which case the conflict is even more severe. However, in most of the time, the community's internal question, the everyday politics, is concerned with the re-distribution of public goods.

103 ARENDT, Hannah. On Revolution, intr. Jonathan Schell. New York: Penguin Books, 2006, p. 19 , p. 25 , pp. $132-133$.

104 Hirschl defends the argument that there is support from politicians to the judges' growth of 
before the people (remember that they are not elected in Brazil and have a lifelong tenure, besides other privileges and protections) and they do not have the burden of justifying the political criteria for the redistribution that they are doing in practice: they do not accept calling it "politics," but call it "law."Consequently they approach it in a technical, and not in a political, fashion. Moreover, judges only act when provoked in a lawsuit, so that, in their narrative, they just "implement the Constitution" in the specific and concrete case.

By this technical - merely legal and not political - selfunderstanding, the judiciary turns out to hide the political aspect of the discussion. However, behind something they call legal, it is just charity: using the legal "technical" term "right" they ignore the political and distributional aspects of the situation. ${ }^{105}$ They actually are doing politics, but without the burden of accountability before the people. In this way, the discussions are reached just by some juristocrats, in a hermetic realm; and not in the public sphere, where everyone is able to participate.

\section{Conclusions}

It is symptomatic to see that most of the articles on the subject in Brazil are launched with the following problem: "how to limit the judiciary?"106 This not only shows who has effectively exercised the power to decide and implement public health policies in Brazil, but in a subtle way also shows that the judiciary is accumulating the functions that should be in the Executive branch (implementing public policy) and in the Legislative branch (deciding public policy). ${ }^{107}$ On the other hand, those who stand for a more favorable view on the individual justiciability of social rights, are dedicated to write about how the judiciary can "democratize" itself or to technically develop tools to be able to implement its own rulings in a more just and democratic way.

power (HIRSCHL, Ran. "The New Constitutionalism and the Judicialization of Pure Politics Worldwide, 2006).

105 LOPES, José Reinaldo de Lima. "Judiciário, democracia, políticas públicas, 1994, p. 255. 106 TESSLER, Marga Inge Barth. "Medicina baseada em evidências e o direito à saúde, 2009; .LOPES, José Reinaldo de Lima. "Judiciário, democracia, políticas públicas”, 1994;BORGES, Danielle da Costa Leite; UGÁ, Maria Alicia Dominguez. "As Ações Individuais para o Fornecimento de Medicamentos no âmbito do SUS, 2009, among others.

107 It is still interesting to see the shock of a Federal Court's judge reporting that she was invited to a medical congress as a "specialist" to discuss issues as "perspectives around ... 1) coated stents vs. uncoated ones for acute coronary syndrome; 2) monoclonal antibodies for the treatment of psoriasis; and 3) calcium for prevention of hypertension in pregnancy and its consequences" (TESSLER, Marga Inge Barth."Medicina baseada em evidências e o direito à saúde, 2009). 
That is, on the one hand we see that the judiciary actually has exercised powers that, in principle, should be exercised by other powers $^{108}$ which are, in their turn, more accountable in the public sphere. And, on the other hand, we see that the judiciary has been trying to catch up, and growing its legitimacy, in order to exercise such power. In other words, it is incorporating typical legislative procedures (public hearings, for example) and executive ones (hiring technical professionals from different areas, for instance) in its quotidian work: the judiciary is turning itself into a great power, which accumulates legislative, executive and judicial tasks. ${ }^{109}$

If on one hand such measures help the judiciary to better handle the distributive aspects involved in cases that deal with social rights for, as Hirschl points out, judicialization "has been accompanied by the concomitant assumption that courts - not politicians or the demos itself - are the appropriate forums for making these key decisions" ${ }^{\prime 10}$ - such procedure raises the question: instead of match the Executive and the Legislative, would not be better - and more according to the Constitution - allowing such powers exercise their functions by themselves?

One of the judiciary's defenders argument is the inertia and the ineffectiveness of the legislative and executive in the implementation of social rights. ${ }^{111}$ Rights under the Constitution cannot be just in the promise, they argue. ${ }^{112}$ The inertia and inefficiency, however, does not seem to be an argument that is sustained by itself. First it cannot be universalized: certainly the judiciary would not agree with the legislative and the executive judging the lawsuits that are lying in courts' shelves for years throughout Brazil. Second, with the increasing judicialization, it is the judiciary that will begin to be ineffective (as it already actually is) due to the increase in the number of cases. And finally mere a judicial order does not solve the real problem, but just shifts it: to pay for the medicine provided by judicial order it is necessary to take the money and investment from another area (education, security, etc.) if not from health itself.

In fact, what judges do in these individual cases is to express a political disagreement with the public policy established in the public

108 VENTURA, Miriam et al. "Judicialização da saúde, acesso à justiça e a efetividade do direito à saúde", 2010, p. 96.

109 LOPES, José Reinaldo de Lima. "Em torno da 'Reserva do Possível”, 2008, p. 172.

110 HIRSCHL, Ran. "The New Constitutionalism and the Judicialization of Pure Politics Worldwide, 2006, p. 722.

111 BARBOZA, Estefânia Maria de Queiroz; KOZICKI, Katya. "Judicialização da política e controle judicial de políticas públicas."Revista Direito GV 8, n.1 (Jun, 2012): 59-85, p. 73. Available at www.scielo.br.

112 Min. Marco Aurélio, RE 368564, 75. See also Min. Ayres Britto, RE 368564, 87. See also: SILVA, Virgílio Afonso da. "O Judiciário e as políticas públicas: entre transformação social e obstáculo à realização dos direitos sociais.”, 2008, p. 588. 
sphere by the legislative and implemented by the executive. Actually they are saying that they believe that Brazil should have more money for health, and not for other things. In a sense it is a kind of arrogance (in the absence of a better expression) which comes between the lines of Hirschl's quote. For the judiciary, the budget was not "properly"113 distributed and it is up to the judges, in that standpoint, to solve the social problem ${ }^{114}$ - the implicit discourse here is a self-understanding that only the judges (and not all the powers, or the population itself) can or should implement the Constitution. The only criteria they have to say that the budget was not properly distributed is by the fact that they themselves disagree with the budget - that is, they disagree with the criterion of distribution, but they raise this disagreement in terms of legality and not in terms of politics.

In other words, judges in these cases are trying to establish a policy, but in a hidden way, and not at the public realm. The judiciary becomes a political arena, ${ }^{115}$ but not a public one. In fact it excludes the people from debate about the distribution. And such a policy does not come with typical arguments of policy (distributive), but with individualistic and charitable arguments. ${ }^{116}$

However, is not only the judiciary that holds the task to implement the Constitution.Certainly the individual lawsuits of social rights will not solve the problem as a whole. It would help more if it fulfilled its role to apply the distributive criteria instead of trying to create or change them. Rather than trying to be executive and legislative, why not let each branch fulfill its own constitutional role?

There is some hope for lucidity, however. We believe the question on the individual actions demanding social rights in Brazil can begin to take a more rational course. The STF recently selected an exemplary case of this controversy to judge it in a special procedure called in Portuguese "Repercussão Geral." In this procedure - which is quite new in Brazilian law - the Court decides one singular case as an example of the issue (it is not collective action, however; it is still one regular individual case) as if they were ruling all similar several other repetitive cases about the same matter. That is, in this kind of judgment

113 BARBOZA, Estefânia Maria de Queiroz; KOZICKI, Katya. "Judicialização da política e controle judicial de políticas públicas.”, 2012, p. 73.

114 BARBOZA, Estefânia Maria de Queiroz; KOZICKI, Katya. "Judicialização da política e controle judicial de políticas públicas.”, 2012, p. 65.

115 BARBOZA, Estefânia Maria de Queiroz; KOZICKI, Katya. "Judicialização da política e controle judicial de políticas públicas.”, 2012, p. 65.

116 We emphasize again that this criticism applies only to cases of individual actions that postulate social rights individually. The lawsuits challenging public policy as a whole deserve a different approach, especially because they allow the judge to see the relational whole (distributive) of the question. In collective action, at least in principle, there is no room for charity. 
broader arguments are also analyzed, including by listening to experts on the subject and interested social groups. Despite the fact that the case is still the judgment of an individual and concrete case, it is used as a parameter for all other similar, so that arguments are not limited to individual right, but they also raise distributive arguments. Two casesare under this procedure right now. The "Recurso Extraordinário No. 566471," which discusses the supply of high-cost medicines that are not included in the public policy's list and the "Recurso Extraordinário No. 657718" which discusses the provision of medicines that were not approved or which does not have a register in the regulatory agency. It is possible that such judgments, which have not yet occurred, will consider the distributional and political aspect of the issue, and not just the individual or charity arguments.

\section{REFERENCES}

ALEXY, Robert. Teoria dos Direitos Fundamentais. Trad. Virgílio Afonso da Silva. São Paulo: Malheiros, 2008.

ARENDT, Hannah. On Revolution, intr. Jonathan Schell. New York: Penguin Books, 2006.

ARISTOTLE. "Nicomachean Ethics." In The Complete Works of Aristotle, edited by Jonathan Barnes, 1729-1867. Princeton: Bollingen Series LXXI 2 , Volume Two. Sixth Printing, 1995.

ATRIA, Fernando. "El Derecho y la contingencia de lo político", Doxa, n. 10, 1991 (pp. 319-345).

“Existen Derechos Sociales?” Discussiones: Derechos Sociales n. 4 (2004): 15-59.

BARBOZA, Estefânia Maria de Queiroz; KOZICKI, Katya. "Judicialização da política e controle judicial de políticas públicas."Revista Direito GV 8, n.1 (Jun, 2012): 59-85. Available at www.scielo.br

BAYÓN, Juan Carlos. "Democracia y derechos: problemas de fundamentación del constitucionalismo". In:CARBONELL, Miguel y JARAMILLO, Leonardo García (coord.) El canon neoconstitucional. Madrid: Trotta, 2010.

BOBBIO, Norberto. A Era dos Direitos. Trad.: Nelson Coutinho. Rio de Janeiro: Elsevier, 2004.

BRASIL. Constitution of the Federative Republic of Brazil. Available at http://www.stf.jus.br/repositorio/cms/portalStfInternacional/ portalStfSobreCorte_en_us/anexo/constituicao_ingles_3ed2010.pdf 
BORGES, Danielle da Costa Leite; UGÁ, Maria Alicia Dominguez. "As Ações Individuais para o Fornecimento de Medicamentos no âmbito do SUS: Características dos Conflitos e Limites para a Atuação Judicial."Revista de Direito Sanitário 10, n. 1 (Mar./Jul. 2009): 13-38. Available at www.scielo.br

CAMPBELL, Tom. Prescriptive Legal Positivism: Law, Rights and Democracy. London: UCL Press, 2004.

CARIAS, Claudia Mezleveckas; VIEIRA, Fabíola Sulpino; GIORDANO, Carlos V; Zucchi, Paola."Exceptional circumstance drug dispensing: history and expenditures of the Brazilian Ministry of Health.”Revista Saúde Pública 45, n. 2 (2011): 233-240.

CAVALCANTI, Hylda. Brasil tem mais de 240 mil processos na área de Saúde. Site do CNJ. April25th, 2011. Available at http://www.cnj.jus. br/noticias/cnj/14096:brasil-tem-mais-de-240-mil-processos-na-areade-saude.

FERRAZ, Octavio Luiz Motta. "Brazil, Health Inequalities, Rights and Courts." In: Litigating Health Rights: Can Courts Bring More Justice to Health? Edited by Alicia Ely Yamin and Siri Gloppen. Cambridge: Harvard University Press, 2011.

; VIEIRA, Fabiola Sulpino. "Direito à saúde, recursos escassos e equidade: os riscos da interpretação judicial dominante."Dados $52, \mathrm{n}$. 1 (2009): 223-251.

GUASTINI, Riccardo. La "constitucionalización" del ordenamiento jurídico: el caso italiano. In: CARBONELL, Miguel (Ed.). Neoconstitucionalismo(s). Madrid: Trotta, 2003 (pp. 49/74)

HIEBERT, Jane L. "Governing like judges?" In: CAMPBELL, Tom, EWING, K.D and TOMKINS, Adam (Eds.). The Legal Protection of Human Rights:skeptical essays. Oxford: Oxford University Press, 2011

HIRSCHL, Ran. "The Judicialization of Mega-Politics and the Rise of Political Courts." Annual Review of Political Science 11 (2008). Available at SSRN: http://ssrn.com/abstract=1138008

"The New Constitutionalism and the Judicialization of Pure Politics Worldwide." Fordham Law Review 75, n. 2 (2006): 721-54. Available at SSRN: http://ssrn.com/abstract $=951610$

; ROSEVAR, Evan. Constitutional Law Meets Comparative Politics: socio-economic rights and political realities. In: CAMPBELL, Tom, EWING, K.D and TOMKINS, Adam (Eds.). The Legal Protection of Human Rights:skeptical essays. Oxford: Oxford University Press, 2011. 
HOLMES, Stephen; SUNSTEIN, Cass R., The Cost of Rights: why liberty depends on taxes. New York: North \& Co., 1999

KAVANAGH, Aileen. Constitutional Review under the UK Human Rights Act. Cambridge: Cambridge University Press, 2009.

KELSEN, Hans. Pure Theory of Law. Translated from the Second Edition by Max Knight. Berkeley: University of California Press, 1967.

LOPES, José Reinaldo de Lima. "Brazilian Courts and Social Rights: A Case Study Revisited." In Courts and Social Transformation in New Democracies: An Institutional Voice for the Poor?, edited by Roberto Gargarella, Pilar Domingo, Theunis Roux, 185-211. Hampshire: Ashgate Publishing, Ltd., 2006.

. "Direito Subjetivo e Direitos Sociais: o dilema do Judiciário no Estado Social de Direito."Direitos Humanos, Direitos Sociais e Justiça, edited by José Eduardo Faria. São Paulo: Malheiros, 2002.

. "Em torno da 'Reserva do Possível."Direitos Fundamentais: Orçamento e Reserva do Possível, edited by Ingo Wolfgang Sarlet, Luciano Benetti Timm, 155-73. Porto Alegre: Livraria do Advogado, 2008.

"Judiciário, democracia, políticas públicas." In Revista de Informação Legislativa 31, n. 122 (Mai/Jul, 1994): 255-265.

MACEDO, Eloisa Israel de; LOPES, Luciane Cruz; Barberato-Filho, Silvio. "A technical analysis of medicines request-related decision making in Brazilian courts." Revista Saúde Pública 45, n. 4 (2011): 706-13. Available at www.scielo.br/rsp

SILVA, Virgílio Afonso da. "O Judiciário e as políticas públicas: entre transformação social e obstáculo à realização dos direitos sociais." In Direitos Sociais: fundamentação, judicialização e direitos sociais em espécies, edited by Cláudio Pereira de Souza Neto and Daniel Sarmento. Rio de Janeiro: Lumen Juris, 2008: 587-99.

; TERRAZAS, Fernanda Vargas. "Claiming the Right to Health in Brazilian Courts: the exclusion of the already excluded." Law and Social Inquiry, Forthcoming, 2008. Available at http://ssrn.com/ abstract $=1133620$ or http://dx.doi.org/10.2139/ssrn.1133620.

TESSLER, Marga Inge Barth. "Medicina baseada em evidências e o direito à saúde."Revista de Doutrina da $4^{a}$ Região 29 (Abr. 2009). Available at http://www.revistadoutrina.trf4.jus.br/artigos/edicao029/ marga_tessler.html

TREZI, Humberto; OTERO, Julia. “Com 113 mil processos, RS é campeão nacional em ações judiciais na saúde."Jornal Zero Hora. 
November 17th, 2013. Available at http://zh.clicrbs.com.br/rs/noticias/ noticia/2013/11/com-113-mil-processos-rs-e-campeao-nacional-emacoes-judiciais-na-saude-4336052.html

TUSHNET, Mark. Weak Courts, Strong Rights: judicial review and social welfare rights in comparative constitutional law. Princeton and Oxford: Princeton University Press, 2008.

VENTURA, Miriam et al. "Judicialização da saúde, acesso à justiça e a efetividade do direito à saúde." Physis: Revista de Saúde Coletiva 20, n. 1 (2010): 77-100. Available at www.scielo.br

VIEIRA, Fabiola Sulpino. "Ministry of Health's spending on drugs: program trends from 2002 to 2007." Revista Saúde Pública 43, n. 4 (2009): 674-681.

. "Right to health litigations: a discussion on the observance of the principles of Brazil's Health System." Revista Saúde Pública 42, n.2 (2008): 365-9. Available at www.scielo.br/rsp

; Zucchi, Paola."Distortions to national drug policy caused by lawsuits in Brazil.” Revista Saúde Pública 41, n. 2 (2007): 214-222.

; Zucchi, Paola. "Patient Lawsuits and Treatment Provision on the Brazilian National Health Service." Revista Associação Médica Brasileira 55, n.6 (2009): 672-83. Available at www.scielo.br

WALDRON, Jeremy. Law and Disagreement. Oxford and New York: Oxford University Press, 1999.

. "The Core of the Case Against Judicial Review". The Yale Law Journal, 115: 1346, 2006. 